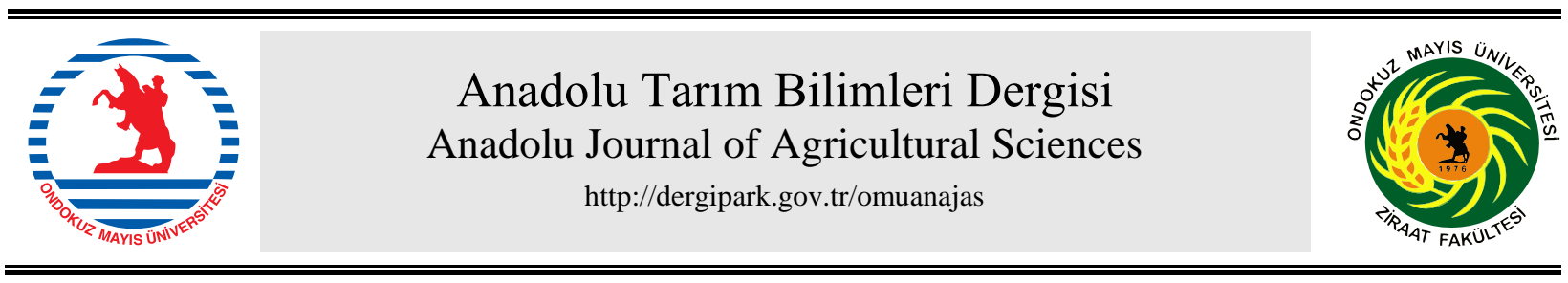

\title{
Araş̧tırma/Research
}

Anadolu Tarım Bilim. Derg./Anadolu J Agr Sci, 35 (2020) ISSN: 1308-8750 (Print) 1308-8769 (Online) doi: $10.7161 /$ omuanajas.596708

\section{Soğutma sistemli bir seyyar süt sağım makinasının soğutma performansının belirlenmesi}

\author{
Taner Akbaş ${ }^{\mathrm{a}^{*}}$, Cengiz Özarslan ${ }^{\mathrm{b}}$, Mustafa Çetin ${ }^{\mathrm{c}}$ \\ ${ }^{a}$ Aydın Adnan Menderes Üniversitesi, Aydın Melek Yüksekokulu, Aydın \\ ${ }^{b}$ Aydın Adnan Menderes Üniversitesi, Ziraat Fakültesi, Biyosistem Mühendisliği Bölümü, Aydın \\ ${ }^{c}$ Aydın Adnan Menderes Üniversitesi, Söke İsletme Fakültesi, Yönetim Bilişim Sistemleri Bölümü, Aydın
}

*Sorumlu yazar/corresponding author: taner@adu.edu.tr

Geliş/Received 25/07/2019 Kabul/Accepted 20/11/2019

\begin{abstract}
ÖZET
$\mathrm{Bu}$ çalışmada seyyar tip kovalı süt sağım makinaları için bir soğutma sistemi geliştirilmiş ve laboratuvar ortamında yaş koşullarda denemeleri gerçekleştirilmiştir. Ortaya konulan makina ile özellikle süt soğutma tankı ve süt sağım tesisi bulunmayan küçük işletmelerde sağım esnasında, sütün soğuk zincire girene kadar geçen sürede soğutularak kalitesinin muhafaza edilmesi ve ekonomik değer kaybının önüne geçilmesine çalışılmıştır. Seyyar süt sağım makinalarında bulunan süt kovasına bir soğutma sistemi entegre edilerek toplanan süt, sağım sırasında soğutulmaya başlanmıştır. Denemeler laboratuvar ortamında su ile gerçekleştirilmiştir. Prototip makine, 88 dakika sonunda suyu hedeflenen sıcaklık olan $3{ }^{\circ} \mathrm{C}$ 'ye indirmeyi başarmıştır. Yaklaşık 13 saatlik deneme süresinde toplam enerji tüketimi ise $1.8 \mathrm{kWh}$ olmuştur.
\end{abstract}

Determination of cooling performance of a mobile type milking machine with cooling system

\section{ABSTRACT}

In this research, a cooling system for mobile type milking machines was developed and its experiments were carried out in the laboratory under wet conditions. Thus, especially in small animal farms which do not have milk cooling tank and milking systems, it was tried to maintain the quality of milk by cooling and to prevent economic loss. The milk was cooled during milking time by integrating a cooling system to the milk bucket on mobile type milking machines. Experiments were carried out by water in laboratory conditions. Prototype machine was able to lower the temperature of water to $3{ }^{\circ} \mathrm{C}$ at the end of 88 minutes. Total energy consumption during the test period of approximately 13 hours was $1.8 \mathrm{kWh}$.

Anahtar Sözcükler: Seyyar süt sağım makinas Soğutma Yaş koşullar

Bu çalışma Aydın Adnan Menderes Üniversitesi Bilimsel Araştırma Projeleri tarafından desteklenmiştir. Proje No: ZRF-13018 


\section{Giriş}

Çĭg süt, birçok gıda maddesinin hammaddesini oluşturmaktadır. Çiğ sütün işleninceye kadar soğutularak muhafaza edilmesi gerekmektedir. Süt ürünlerinin işlenmesinde, verimlilik ve kalite açısından, işlenecek bu hammaddenin içeriği itibariyle zengin, temiz ve sağliklı olması gerekmektedir. Bütün bu koşulları sağlayabilmek amacıyla kullanılan süt sağım makineleri ve süt sağım tesisleri entansif süt sığırcıllğg işletmelerinin vazgeçilmez araçlarıdır. $\mathrm{Bu}$ araçlarla sağım mekanizasyonu ve otomasyon sağlanmakta, bunun yanında süt, daha yüksek verimde, hijyenik olarak elde edilebilmektedir (Sağlam ve ark., 2015). Süt sığırcıllı̆ıında sağım, işletme içerisinde yapılan işlerin büyük bir kısmını oluşturmaktadır. Mekanizasyon olanağı olmayan ve işgücünden yoğun olarak yararlanılan işletmelerde sağım için harcanan zaman daha fazla olmaktadır. Bu nedenle sağım, süt sığırcılığı işletmelerinde önemle üzerinde durulması gereken günlük işlerden biridir (Alıç ve Yener, 2006). Makinalı sağım uygulamaları ve sağım teknolojisindeki gelişmeler her şeyden önce sağıma harcanan zamanın azaltılmasını, daha az insan işgücü ve enerji tüketimi ile fazla sayıda hayvanın sağlıklı bir şekilde sağılmasını ve daha hijyenik sağım koșulları sağlayarak temiz süt elde edilmesini amaçlamaktadır (Işık ve Ünal, 2003).

Zengin besin maddesi içeriğinde, zararlı mikroorganizmalardan mümkün olduğunca arındırılmış, hijyenik ortamın sağlandığı koşullarda elde edilen çiğ süt, üretildiği hayvanc1lık işletmelerindeki tanklarda soğutulmakta ve muhafaza edilmektedir (Günhan ve ark., 2006; Erginkaya ve ark., 2001). İçerisinde yararlı ve zararlı birçok bakteri, maya ve küf mantarları bulunan süt, dünyadaki en besleyici maddelerden bir tanesidir (Günhan ve ark., 2006). Yeni sağılan ve vücut sicaklığında $\left(35-37{ }^{\circ} \mathrm{C}\right)$ olan süt, en kısa sürede soğutulmalıdır. Aksi takdirde, mikroorganizmalar hızla çoğalarak sütün bozulmasına neden olurlar (Demir ve ark., 2016). Bakteriler bölünerek çoğalan canlılar olduğundan uygun ortam koşullarını bulan bakterilerin sayıları zaman ilerledikçe logaritmik bir şekilde artmaktadır. Bakterilerin bölünerek çoğalma süresi bakterinin tipine ve ortam sicaklığına göre değişmektedir. Sütteki tüm bakteriler dikkate alındığında bakteri sayısının iki katına çıkma süresi ortalama 1 saat kadardır. Ancak bazı bakteriler (kolibakterileri) için bu süre 20 dakika kadardır. Zararlı bakteriler yararlı bakterilere göre hem daha hızlı çoğalmakta hem de yararlı bakterilerin çoğalamadıkları düşük sıcaklıklarda yavaş da olsa çoğalabilmektedirler. Çiğ sütün bakteri içeriği, $1 \mathrm{ml}$ sütte ne kadar mikroorganizma olduğu ile ifade edilir. "Çiğ Süt ve Isıl İşlem Görmüş İçme Sütleri Tebliği" ne (Tebliğ No: 2000/6) göre çiftlikten işletmeye gidecek çiğ inek sütünün 1 mililitresindeki bakteri sayısının 100 000'den az, somatik hücre sayısının 500 000'den az olması gerekmektedir (Anonim, 2010).

İnsanlar için bir besin kaynağı olan süt, mikroorganizmaların gelişimi için de uygun bir ortamdır. Mikroorganizma gelişimini engellemek için alınan önlemler çiğ sütün kalitesini belirlemektedir ve sağımdan sonra sütün hemen soğutulması uygulanabilecek en iyi yöntemdir. Soğutmanın yapılamadığı, soğuk zincirin kurulamadığı 1lıman ve sıcak iklim bölgelerinde sütün mikrobiyolojik kalitesi hızla bozulmaktadır (Erginkaya ve ark., 2001). Sütün doğal niteliğinin koruyabilmenin başlica yolu bakteri etkinliğini frenlemektir. Bunun için de sütü sağar sağmaz hemen $10{ }^{\circ} \mathrm{C}$ 'nin altına soğutmak, bakteri etkinliğinin yoğun olduğu sıcaklıktan uzaklaştırmak gerekir (Üçüncü, 1983).

Hayvancılık işletmelerinde kurulu bulunan sağım tesislerinde süt, sağım esnasında doğrudan süt soğutma tanklarına gönderilmektedir. Süt soğutma tanklarından, dış ortam sıcaklığına bağlı olarak sütü 2.5-3.5 saat içinde $4{ }^{\circ} \mathrm{C}$ 'nin altına düşürmesi beklenmektedir. Ekonomik olarak süt sağım tesisi kurma imkânına sahip olmayan, hayvan sayısı az ya da sürüden ayrı sağılması gereken işletmelerde seyyar tip süt sağım makinaları kullanılmaktadır. Süt kovasına sahip bu makinalarda sağılan süt, süt toplama merkezine ulaştırılana kadar dış ortam koşullarında bekletilmektedir. Bu esnada sütün içerisinde mikroorganizma faaliyetleri artmakta, süt kalitesi düşmekte dolayısıyla ekonomik değer kaybı oluşmaktadır. Zengin mikroorganizma içeren süt, diğer sütlerle karıştırıldığında zarar daha da büyümektedir. Ayrıca "Çiğ Sütün Sözleşmeli Usulde Alım Satımına İlişkin Yönetmelik " gereği sanayiye arz edilen çiğ sütün alım ve satımının sözleşmeli usulde yapılması zorunlu hale gelmiştir. Ulusal Süt Kayıt Sistemi üzerinden yapılan duyuruda 2016 yılında yapılacak çiğ süt desteklemelerinde sütün soğutulmuş ve sözleşmeli olarak satılmış olması şartı getirilmiş olup, üretmiş olduğu sütü soğutmadan ve sözleşmesiz satan üreticilerin çiğ süt desteklemesinden yararlanamayacağ belirtilmiştir (Anonim, 2015).

$\mathrm{Bu}$ çalışmada seyyar süt sağım makinası kullanan işletmelere yönelik olarak makine üzerine bir soğutma sistemi entegre edilmesi ve böylelikle sütün güvenilir bir şekilde muhafaza edilmesi amaçlanmıştır.

\section{Materyal}

Ortaya konulan prototip makine, süt sağım sistemi ve soğutma sistemi olmak üzere iki kısımdan oluşmaktadır. Bu iki ana kısım bir çatı üzerine monte edilmiş olup, taşıma tekerlekleri vasıtasıyla hareket ettirilmektedir (Şekil 1). 


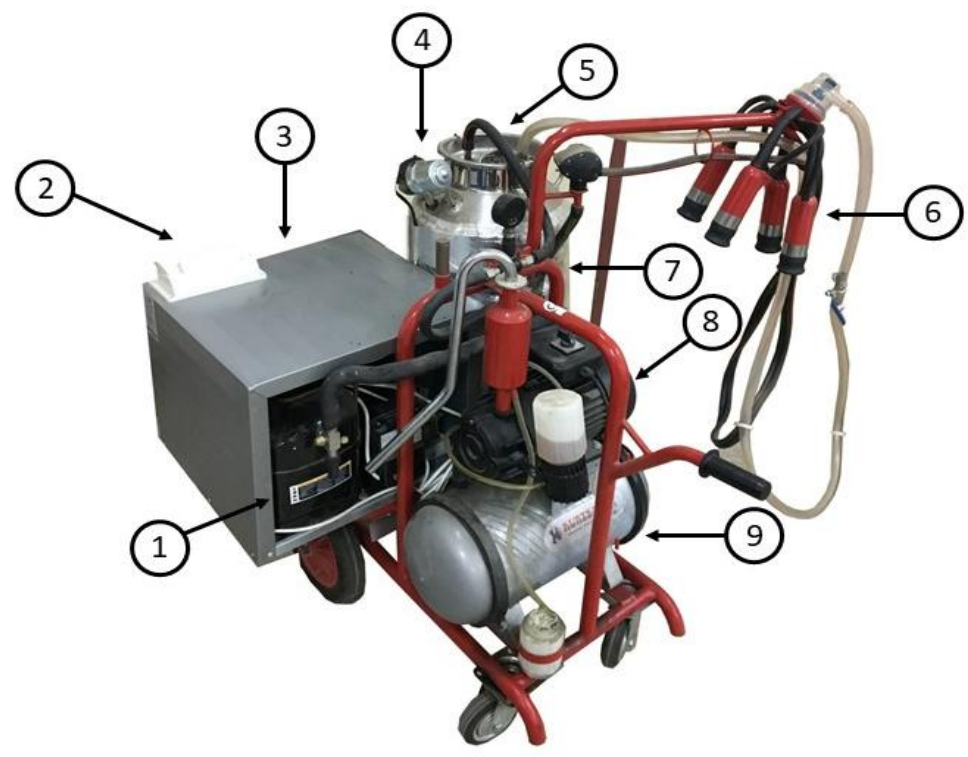

Şekil 1. Prototip makinanın genel görünüşü;

1. Kompresör, 2. Dijital termostat, 3. Yoğuşturucu, 4. Karıştırıcı motoru, 5. Süt kovası, 6. Sağım başlıkları

7. Buharlaştırıcı, 8. Vakum pompası, 9. Vakum deposu

Figure 1. General view of the prototype machine;

1. Compressor, 2. Digital thermostat, 3. Condenser, 4. Mixer motor, 5. Milk bucket, 6. Milking clusters,

7. Evaporator, 8. Vacuum pump, 9. Vacuum tank

Seyyar süt sağım makinası; vakum pompası, elektrik motoru, vakum deposu, regülatör, vakummetre, pulsatör, sağım başlığı ve süt kovasından oluşmaktadır. $\mathrm{Bu}$ sisteme entegre edilen soğutma sistemi ise kompresör (ekovat), evaporatör (buharlaştırıcı), kondenser (yoğuşturucu) ve yardımcı donanımlardan (genleşme valfi, mikro işlemcili ve tek kontak çıkışlı dijital göstergeli termostat, kondenser fanı, iletim hatları ve karıştırıcı) oluşmaktadır. Soğutma sistemine ilişkin şematik görünüm Şekil 2'de verilmektedir.

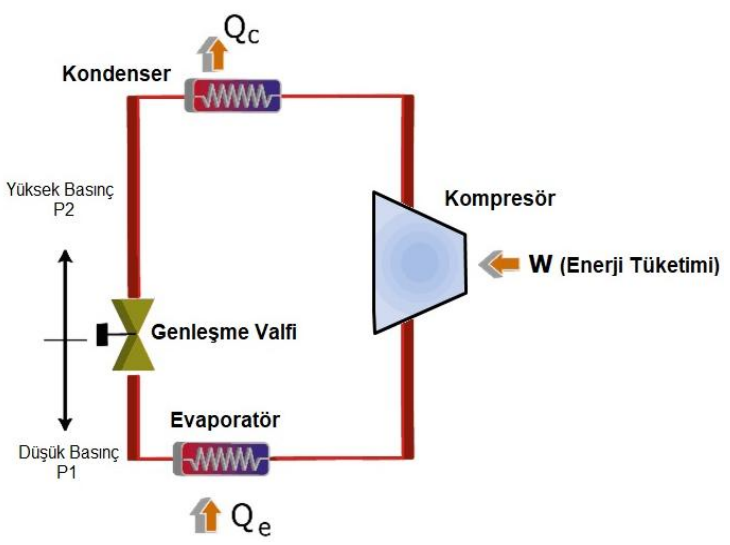

Şekil 2. Soğutma sistemi şematik görünüşü

Figure 2. Schematic view of cooling system

\subsection{Süt să̆ım sistemi}

Çalışmada monofaze elektrik motoruyla tahrik edilen paletli tip vakum pompasına sahip mekanik nabız aygıtlı, çift sağım başlıklı ve çift kovalı bir seyyar süt sağım makinası kullanılmıştır. Soğutma sisteminin süt sağım sistemine entegre edilmesi sirasında kovalardan ve sağım başlıklarından birer tanesi çıkarılarak süt sağım sistemi tek sağım başlıklı olarak kullanılmıştır. Süt kovası şase üzerine sabitlenmiş olup içerisindeki sütün ve temizleme sıvısının boşaltılabilmesi için kovanın tabanına bir tahliye pompası ve vanası yerleştirilerek hortumla bağlantısı sağlanmıştır (Şekil 3). Kullanılan makinaya ait teknik özellikler Çizelge 1'de verilmiştir.

\subsection{Soğutma sistemi}

Soğutma sisteminde yer alan evaporatör, süt kovasının dış yüzeylerine sarılan bakır borulardan oluşmaktadır. Soğutma akışkanı tipi R22'dir. Kompresör ve kondenser, kovanın yanında çıkarılan süt kovasının yerine şase üzerine yerleştirilmiştir. Kovanın içerisindeki sütün homojen bir şekilde soğutulabilmesi amacıyla döner tip mekanik bir karıştırıcı kullanılmıştır. Karıştırıcı kovanın dişına yerleştirilen 12 Volt'luk, 48 rpm devirli ve $2 \mathrm{Nm}$ momente sahip bir DC motorla tahrik edilmektedir (Şekil 4). Karıştırıcıya manuel 
olarak komuta edilmektedir. Soğutma sistemine ait teknik özellikler Çizelge 2'de verilmiştir.

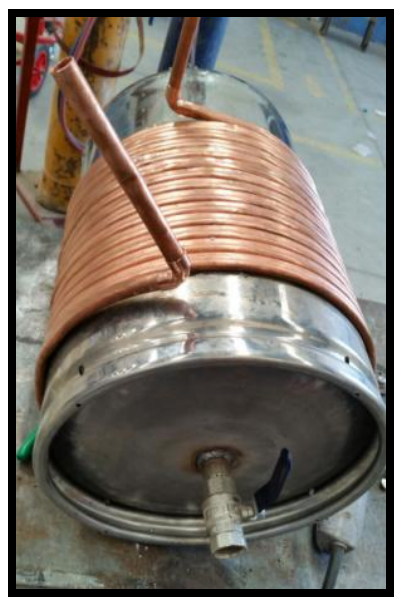

Şekil 3. Süt kovas1

Figure 3. Milk bucket

Çizelge 1. Denemeye alınan süt sağım makinasının teknik ve fiziksel özellikleri

Table 1. Technical and physical properties of the milking machine taken for experiments

\begin{tabular}{|c|c|c|}
\hline \multicolumn{2}{|l|}{ Güç Kaynağ 1} & $\begin{array}{l}220 \mathrm{~V}, 50 \mathrm{~Hz}, 0.75 \mathrm{HP}, \text { Monofaze elektrik } \\
\text { motoru }\end{array}$ \\
\hline \multicolumn{2}{|c|}{ Hareket İletim Sistemi } & Elektrik motoru pompaya direkt bağlanmıştır \\
\hline Vakum Pompası & Tipi & Paletli - Yağlı \\
\hline \multirow{2}{*}{ Vakum Deposu } & Tipi & Silindirik \\
\hline & Hacmi & 30 litre \\
\hline \multirow{3}{*}{ Nabız Sistemi } & Nabız Aygit1 & Mekanik \\
\hline & Nabız Hareketi & Değişken zamanlı \\
\hline & Nabız Sayısı & 60 \\
\hline \multirow{2}{*}{ Sağım Sistemi } & Uzun nabız hortumu iç çapı & $8 \mathrm{~mm}$ \\
\hline & Uzun süt hortumu iç çap1 & $14 \mathrm{~mm}$ \\
\hline \multirow{2}{*}{ Sağım Başlı̆̆1 } & Ağgırlığ1 & $2350 \mathrm{~g}$ \\
\hline & Pençe iç hacmi & $180 \mathrm{ml}$ \\
\hline \multirow{5}{*}{ Meme Lastikleri } & Kısa süt hortumum iç çap1 & $10 \mathrm{~mm}$ \\
\hline & Kısa süt hortumu uzunluğu & $225 \mathrm{~mm}$ \\
\hline & Etkin uzunluk & $175 \mathrm{~mm}$ \\
\hline & Etkin cap & $25 \mathrm{~mm}$ \\
\hline & Dudak iç çapı & $22.5 \mathrm{~mm}$ \\
\hline \multicolumn{2}{|l|}{ Kova hacmi } & 40 litre \\
\hline \multicolumn{2}{|l|}{ Regülatör } & Yaylı \\
\hline
\end{tabular}

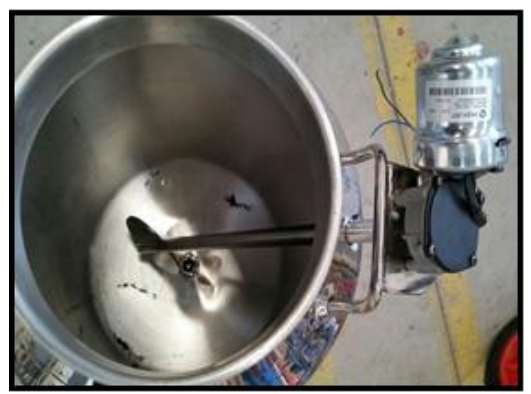

Şekil 4. Karıştırıcı genel görünüşü 
Figure 4. Mixer overview

Çizelge 2. Soğutma sistemine ait teknik özellikler

Table 2. Technical features of cooling system

\begin{tabular}{ll}
\hline Kompresör & $:$ Hermetik \\
\hline Tipi & $: 0 /+45^{\circ} \mathrm{C}$ \\
Çalışma Şartları & $: 2367$ Watt \\
Soğutma Kapasitesi & $: 1 \mathrm{HP}$ \\
Gücü & $: 220 \mathrm{~V} 50 \mathrm{~Hz} 3 \sim$ \\
Beslenme Gerilimi & $:$ Bakır borulu \\
\hline Kondenser & $:+45^{\circ} \mathrm{C}$ \\
\hline Özellikler & $: 1$ adet \\
Çalışma Sıcaklığı & $: 300$ mm \\
Fan Miktarı & $:$ Basınç Kontrollü \\
Fan Çapı & \\
Kontrol & $:$ Bakır boru 16 mm çapında 0.60 mm kalınlık \\
\hline Evaporatör & $:-10{ }^{\circ} \mathrm{C}$ \\
\hline Özellikler & $:$ Dijital mikroprosessör NTC sensör \\
Çalışma Sıcaklığ & Kontrol
\end{tabular}

\section{3. Ölçüm Cihazları}

Denemelerinde dört meme başını temsilen dört adet 2.51 hacme sahip, kauçuk memeli buzağı biberonu kullanılmıştır. Süt kovası içindeki deney suyunun sıcaklığının ölçülmesinde ve kaydedilmesinde, mikro işlemcili, harici prob (80PK-22) bağlanabilen bir IR termometre (Fluke 568) (Şekil 5), diş ortam sıcaklık ölçümlerinde ve kaydedilmesinde ise dijital sıcaklık kayıt cihazı (LYK 20E) kullanılmıştır.
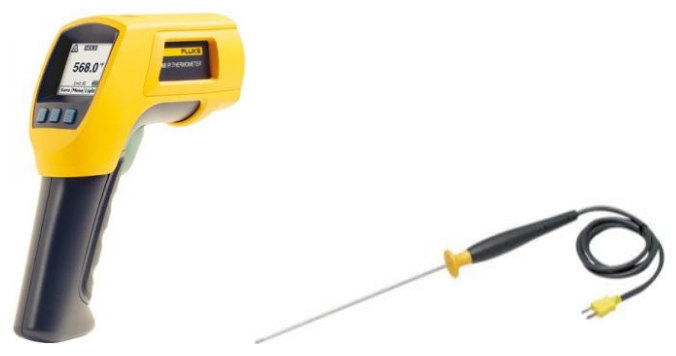

Şekil 5. IR termometre ve sıcaklık ölçüm probu

Figure 5. IR thermometer and temperature measuring probe
Ortaya konulan prototip makinanın soğutma sisteminin enerji sarfiyatı ölçümleri 1 Fazlı, 2 Telli, Demantmetreli, Aktif Elektronik Elektrik Sayacı ile $1600 \mathrm{imp} / \mathrm{kW}$ hassasiyetinde yapılmıştır (Şekil 6).

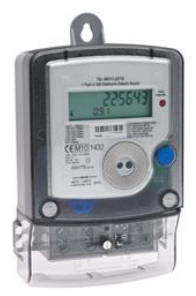

Şekil 6. Denemelerde kullanılan elektrik sayacı

Figure 6. Electric meter used in experiments

\section{Yöntem}

Denemeler laboratuvar koşullarında yaklaşık $32{ }^{\circ} \mathrm{C}$ dış ortam sıcaklığında yürütülmüştür. Yaş koşullarda gerçekleştirilen sağım işlemi $50 \mathrm{kPa}$ vakum basıncında yapılmıştır.

Süt sağım ve soğutma sisteminden oluşan entegre makine, deney başlamadan önce 3 saat denemelerin yapılacağı sicaklıkta bekletilmiştir. Soğutma sisteminin soğutma performansı denemeleri deney suyu kullanılarak gerçekleştirilmiştir. 
Sağım sırasında hayvandan alınan sütün sıcaklığının 35-37 ${ }^{\circ} \mathrm{C}$ olmas 1 nedeniyle deney suyu daldırma tip rezistanslı su isitıcisı kullanılarak $36{ }^{\circ} \mathrm{C}^{\prime}$ ye 1 sitılmıştır. Deney suyu bir meme platformu üzerine yerleştirilmiş olan dört adet buzağı biberonuna doldurularak sağım denemeleri şematik görünümü Şekil $7^{\prime}$ de sunulan deneme düzeneğinde gerçekleştirilmiştir.

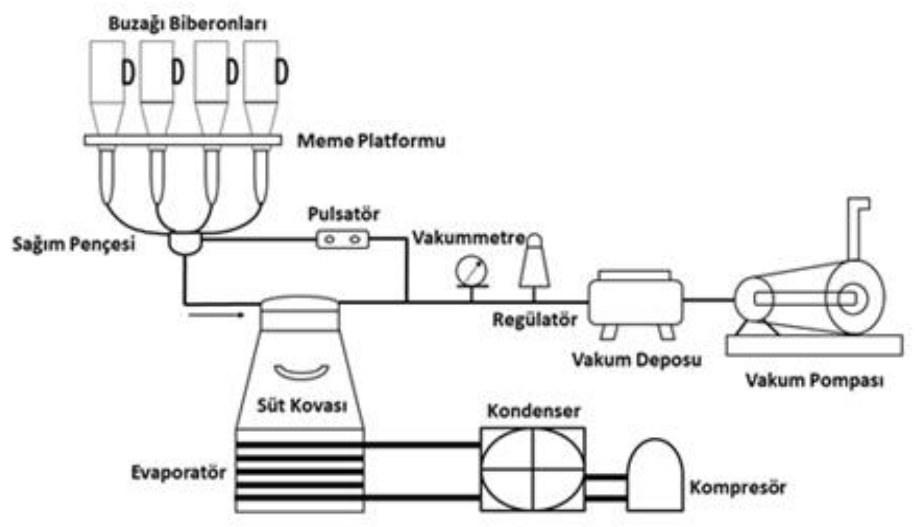

Şekil 7. Deneme düzeneği

Figure 7. The experimental setup

Sağım ve soğutma işlemleri birlikte başlamış ve sıvının homojen bir şekilde soğuyabilmesi için karıştırıcı da devreye alınmıştır. Süt kovası tamamen dolana kadar (40 1) sağım işlemi sürdürülmüş ve kova dolma süresi kronometre yardımıyla ölçülerek sağım debisi belirlenmiștir. Deney suyu sıcaklığının ölçümü, harici probun süt kovasının kapağına açılan contalı bir delikten kovanın merkezine gelecek şekilde suya daldırılmasıyla gerçekleştirilmiştir. Süt kovası içindeki deney suyunun sicaklığı deneme süresince (13 saat 10 dakika) 60 saniyede bir kaydedilmiştir. Elde edilen veriler bilgisayara aktarılarak işlenmiştir.

Soğutma sistemi süt kovasının içerisine konan deney suyu sıcaklığı $3{ }^{\circ} \mathrm{C}$ 'ye inene kadar sürekli olarak çalışmakta ve termostat yardımıyla kapatılmaktadır. Sistem suyun sıcaklığ $1 \quad 4.1{ }^{\circ} \mathrm{C}$ 'ye yükseldiğinde termostat tarafindan açılarak tekrar çalıșmaya başlamakta ve suyu $3{ }^{\circ} \mathrm{C}$ 'ye kadar soğutmaktadır (Anonim, 2010).

Denemeler sırasında süt sağım ve soğutma sisteminin tükettiği elektrik enerjisi, sistemin bağlı olduğu sayaçtan $\mathrm{kWh}$ cinsinden tespit edilmiştir (Anonim, 1999). Sayaç okumaları dört farklı zamanda yapılmıştır. Bunlar; sayacın başlangıç değeri, başlangıç sicaklığından $4{ }^{\circ} \mathrm{C}$ 'a soğutma için geçen süre sonundaki sayaç değeri, başlangıç sıcaklığından soğutma termostatının kapandığı noktaya kadar geçen soğutma süresi sonundaki sayaç değeri ve deneyin tamamlandığı andaki sayaç değeridir.

\section{Araştırma Bulguları ve Tartışma}

Laboratuvar ortamında yaş koşullarda gerçekleştirilen denemeler sonucunda elde edilen bulgular aşağıda sunulmuştur.

\subsection{Deney suyu ve ortam sıcaklı̆̆ değisşimi}

Süt kovası içindeki deney suyu sıcaklığı ve ortam sıcaklığına ilişkin değerler Şekil 8'te sunulmuştur.

Soğutma sistemi devreye girdikten sonra deney suyu sıcaklığı 6. dakikaya kadar artmıştır. Su sıcaklığındaki düşüş bu andan itibaren başlamış ve hedef sıcaklığa (3 $\left.{ }^{\circ} \mathrm{C}\right) 88$ dakika sonunda gelinmiştir. Bu süreden sonra soğutucu içerisindeki soğutucu akışkanın (R22) sıcaklığına bağlı olarak sıcaklık düşüşü $\left(2.3{ }^{\circ} \mathrm{C}\right) 99$. dakikaya kadar devam etmiştir. 100. dakikadan itibaren su sıcaklığı tekrar artmaya başlamış ve bu artış 200 . dakikaya kadar çok düşük miktarlarda gerçekleşmiştir. Diğer bir deyişle, süt kovası deney suyunu, soğutma sistemi devre dişında iken 112 dakika boyunca istenilen sıcaklık sınırlarında muhafaza edebilmiş̧ir. İlk soğutma işlemi gerçekleştikten sonra süt kovası tam dolu kapasitede iken herhangi bir müdahale olmadığ takdirde sistem düzenli olarak devreye girmekte ve su sıcaklığ 1 hedeflenen sinırlar arasında $\left(3{ }^{\circ} \mathrm{C}-4{ }^{\circ} \mathrm{C}\right)$ tutulmaktadır. Soğutma tanklarından beklenen performans değerlerine göre, ortam sıcaklığının $32{ }^{\circ} \mathrm{C}$ olduğu koşullarda sütün $4{ }^{\circ} \mathrm{C}$ altına en çok 3.5 saatte indirilmesi gerekmektedir (Tip B III) (Günhan ve ark., 2006). Soğutma sistemi yaklaşık 1 saat 30 dakikanın altında deneme suyunu $4{ }^{\circ} \mathrm{C}$ 'nin altına düşürme performansıyla Tip B 0 sinıfındadır (Çizelge 3 ve Çizelge 4) (Anonim, 2010). 


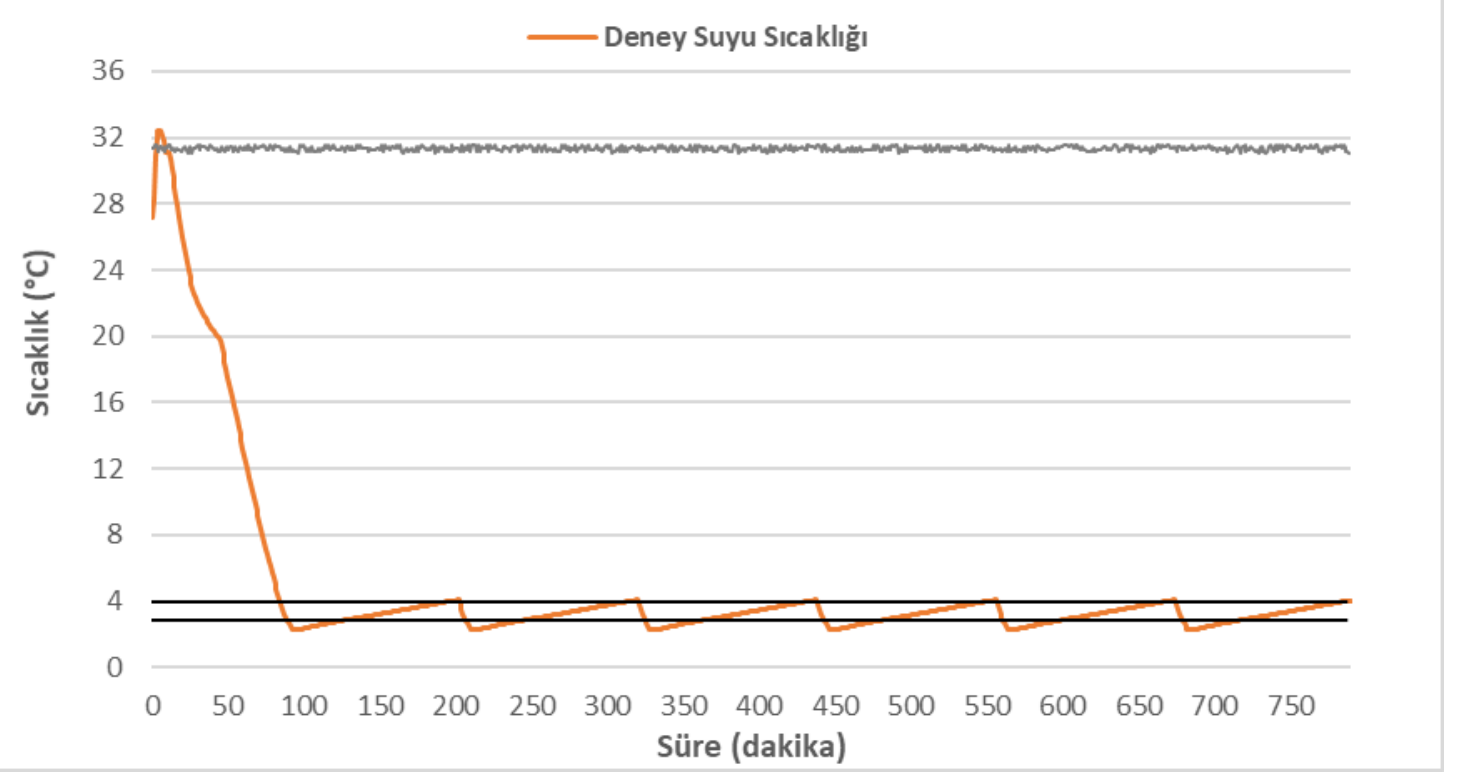

Şekil 8. Zamana bağlı olarak su ve ortam sıcaklık değişim değerleri

Figure 8. Water and ambient temperature change values depending on time

Çizelge 3. Süt soğutma tankının ortam sıcaklığına göre sınıflandırılması

Table 3. Classification of milk cooling tank according to ambient temperature

\begin{tabular}{cc}
\hline Tank Sinıfi & Deney Ortamı Sicaklığ $1\left({ }^{\circ} \mathrm{C}\right)$ \\
\hline A & 38 \\
B & 32 \\
C & 25 \\
\hline
\end{tabular}

Çizelge 4. Süt soğutma tankının süt soğutma süresine göre sınıflandırılması

Table 4. Classification of milk cooling tank according to milk cooling time

\begin{tabular}{lll}
\hline \multirow{2}{*}{ Tank Sınıfi } & $+35{ }^{\circ} \mathrm{C}$ 'den $4{ }^{\circ} \mathrm{C}$ 'ye Bütün Sağımlar için Belirtilen \\
\hline 0 & Soğutma Süresi (h) & \\
\hline I & 2.0 \\
II & 2.5 \\
III & 3.0 \\
\hline
\end{tabular}

\subsection{Enerji tüketim değerleri}

Soğutucu sistemin enerji tüketimine ilişkin veriler Şekil 9'da sunulmuştur.

Soğutma sisteminin anlık enerji tüketim değerleri incelendiğinde, soğutma işlemi boyunca doğrusal bir tüketim olduğu ve bu tüketimin soğutucu ve karıștırıcı devrede iken $0.013-0.014 \mathrm{kWh} / \mathrm{min}$ aralığında olduğu görülmektedir. Soğutucu $36{ }^{\circ} \mathrm{C}$ 'deki deney suyu sıcaklığını $4{ }^{\circ} \mathrm{C}$ 'nin altına indirmek için toplam 1.18 $\mathrm{kWh}$ elektrik enerjisi tüketmiştir. Bununla birlikte, $0.058 \mathrm{kWh}$ enerji tüketimi ile deney suyu $4{ }^{\circ} \mathrm{C}$ 'nin 94 altında 112 dakika muhafaza edilebilmiştir. Bu süreçteki tüketim, soğutma sistemindeki karıştırıcıdan ileri gelmektedir. Soğutma sistemi 112 dakikalık süre sonunda yaklaşık 6 dakika kadar tekrar çalışarak su sıcaklığını $4{ }^{\circ} \mathrm{C}$ 'nin altına düşürerek durmaktadır.

Deneme süresi (13 saat 10 dakika) sonunda kümülatif enerji tüketimi $1.80 \mathrm{kWh}$ olarak elde edilmiştir. 


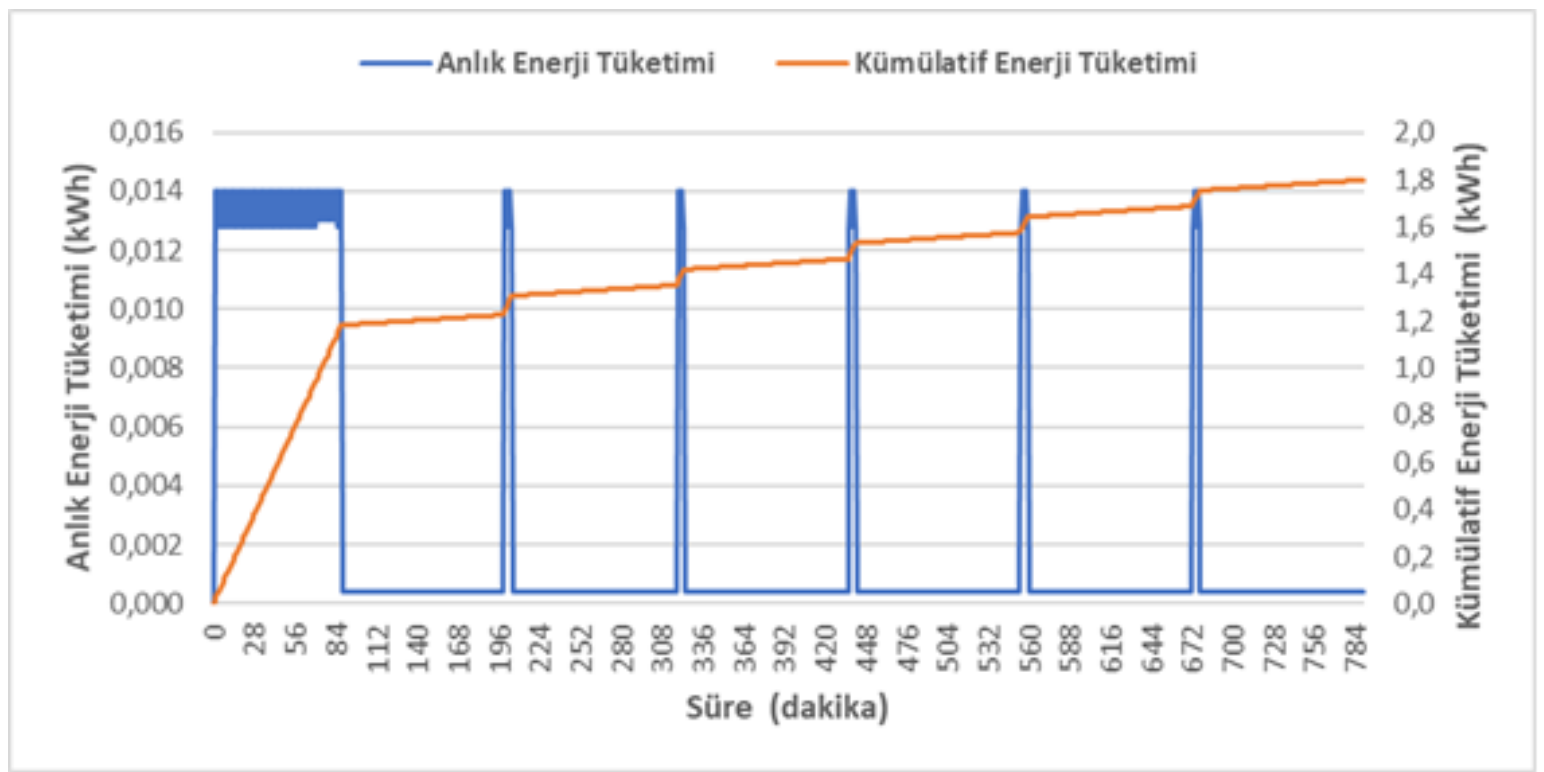

Şekil 9. Zamana bağlı olarak enerji tüketimi

Figure 9. Energy consumption depending on time

\section{Sonuç ve Öneriler}

Küçük ölçekli hayvancılık işletmelerinde süt, toplama merkezine ulaștırılana kadar dış ortam koşullarında bekletilmektedir. $\mathrm{Bu}$ esnada sütün içerisinde mikroorganizma faaliyetleri artmakta ve süt kalitesi düşmektedir. Bu düşüş ekonomik değer kaybına neden olmaktadır.

Tasarım ve imalatı yapılan prototip makine, seyyar soğutmalı bir süt sağım makinasıdır. Makine ile sağılan süt, süt kovasının içinde uygun sıcaklık değerine $\left(4^{\circ} \mathrm{C}\right)$ kadar soğutmakta ve bu sicaklığı muhafaza etmektedir. Özellikle sağım odası ve soğutma tankı bulunmayan küçük ölçekli işletmelerin sütlerini muhafaza edebilmeleri için tasarlanmış olan prototip makine ile ilgili olarak başlıca aşağıda belirtilen sonuç ve önerilere varılmıştır:

- Çalışmada, piyasadaki mevcut donanımlar temin edilerek kullanıldığından yapılarına müdahale edilmemiştir. Bu nedenle prototip makinedeki ünitelerin yapisal olarak daha uyumlu hale getirilmesi uygun olacaktır.

- Makinanın ekonomik etüdü yapılarak küçük işletmelerin kullanımına uygun olup olmadığı belirlenmelidir.

- Prototip makine ilk etapta laboratuvar koşullarında denenmiştir. Makine çiftlik koşullarında de denenerek saha performansının görülmesi yararlı olacaktır. Ayrıca deneme koşullarında başlangıçta ve sonda bakteri sayılarına bakılıp makinanın etkinliği ortaya konmalı ve "Çiğ Süt ve Isı1 İşlem Görmüş İçme Sütleri Tebliği” ne uygunluğu belirlenmelidir (Anonim, 2000).

\section{Teşekkür}

ZRF-13018 nolu Bilimsel Araştırma Projesine destek veren Aydın Adnan Menderes Üniversitesi Bilimsel Araştırma Fonu'na teşekkür ederiz.

\section{Kaynaklar}

Alıç, D., S.M. Yener, 2006. Süt Sığırccilığ1 İşletmelerinde Robotlu Sağım Sistemi, Ankara Üniversitesi Ziraat Fakültesi Tarım Bilimleri Dergisi, 12(4) S:369-380.

Anonim, 1999. Tarım Makinaları Deney İlke ve Metodları. T.C. Tarım ve Köy İşleri Bakanlığı, Tarımsal Üretim ve Geliştirme Genel Müdürlüğü, Ankara.

Anonim, 2000. http://www.resmigazete.gov.tr/arsiv/ 23964.pdf, (Erişim tarihi: 11.07.2019)

Anonim, 2010. TST EN 13732+A2, Türk Standard1 Tasarısı, Gıda İșleme Makinaları-Çiftliklerdeki Dökme Süt Soğutucular-Yapım, Performans, Kullanıma Uygunluk, Güvenlik ve Hijyen Kuralları, Türk Standardları Enstitüsü, Kasım 2010, 57 s.

Anonim, 2015. http://www.resmigazete.gov.tr/eskiler/ 2015/04/20150416.htm, (Erişim tarihi: 11.07.2019)

Demir, V., T. Günhan, A. Şencan Şahin, O. Ekren, H. Bilgen, A. Erek, 2016. Süt Soğutma Tankının Buhar Sıkıştırmalı ve Güneş Enerjili Absorpsiyonlu (LiCl$\mathrm{H}_{2} \mathrm{O}$ ) Soğutma Sistemleriyle Soğutma Performansının Deneysel İncelenmesi, Gazi Üniversitesi Mühendislik-Mimarlık Fakültesi Dergisi, 31(1) S:29-37.

Erginkaya, Z., M. Güven, O., B. Karaca, 2001. Laktoperoksidaz Sistemin Aktivasyonuyla ve 
Soğutularak Korunan Sütlerin Mikrobiyoloik Özellikleri, Gıda Dergisi, 26 (5) S:367-373.

Günhan, T., Demir, V., Bilgen, H., 2006. Çiftlik Tipi Süt Soğutma Tanklarının Performans Değerlerinin Deneysel Olarak Belirlenmesi, Tarım Makinaları Bilimi Dergisi, 2(4)-S:369-379.

Işık, E., Ünal, H., 2003. Yerli Yapım Süt Sağma Makinasının Performans Değerlerinin Saptanmas1, Uludağ Üniversitesi Ziraat Fakültesi Dergisi, 17(1): 79-93.

Sağlam, C., Z.A. Kuş, S. Yılmaz, 2015. Orta Anadolu Süt Sığırcılığı İşletmelerindeki Değişimin Sağım Tesis ve Makineleri Açısından Değerlendirilmesi, Türk Tarım-Gıda Bilim ve Teknoloji Dergisi, 3(2) S:63-66.

Üçüncü, M., 1983. Süt ve Mamullerinin Soğukta Depolanmas1, Gida Dergisi, 8 (4) S:185-192. 